\title{
ВИЗИТНАЯ КАРТОЧКА
}

А. В. Феоктистов, ${ }^{*}$

С. Т. Сулейманова*

\section{ЮРИДИЧЕСКИЙ ФАКУЛЬТЕТ ПЕНЗЕНСКОГО ГОСУНИВЕРСИТЕТА}

\begin{abstract}
Аннотация. В статье рассматривается становление юридического фракультета Пензенского государственного университета. Несмотря на то что факультет является сравнительно молодым, им накоплен большой опыт в учебной, научно-исследовательской работе, международном сотрудничестве, участии в различных проектах. На базе юридического факультета сформирован Центр бесплатной юридической помощи населению. Большую роль в научной работе на факультете играют научно-образовательный чентр "Сравнительная правовая политика», Научно-исследовательский центр по проблемам современного федерализма. Юридический факультет активно развивает международное сотрудничество. Многие преподаватели Университета прошли зарубежные научные стажировки, неоднократно получали гранты на научные исследования в Российском фонде фундаментальных исследований, Российском гуманитарном научном фонде, от зарубежных фондов. Ученые из разных стран (Германии, Бельгии, США, Китая и др.) нередко становятся приглашенными профессорами юридического факультета.
\end{abstract}

Ключевые слова: Пензенский университет, история факультета, учебная деятельность, научная работа, международное сотрудничество, оказание юридической помощи, научные исследования, кафедры.

\section{DOI: 10.17803/1729-5920.2016.116.7.009-013}

4 еленаправленная подготовка юристов в г. Пензе началась лишь в 1996 г., а юридический факультет в составе Пензенского государственного университета был создан в 1998 г.

Первоначально в составе факультета были организованы следующие кафедры: государственно-правовых дисциплин; гражданского права и процесса; истории; политологии и основ права; уголовного права и процесса.

В настоящее время на факультете существует семь правовых кафедр:

- государственно-правовых дисциплин (заведующий кафедрой - доктор юридических наук, профессор Ольга Валентиновна Романовская);

- истории Отечества, государства и права (заведующий кафедрой - доктор исторических наук, профессор Валерий Юрьевич Карнишин);

- правосудия (заведующий кафедрой - кандидат юридических наук, доцент Виктор Александрович Терехин);

(c) Феоктистов А. В., Сулейманова С. Т., 2016

* Феоктистов Александр Владимирович, кандидат юридических наук, заместитель декана юридического факультета по социальной и воспитательной работе Пензенского государственного университета ufdec@pnzgu.ru 440026, Россия, г. Пенза, ул. Красная, д. 40

** Сулейманова Светлана Тимуровна, кандидат социологических наук, кандидат юридических наук, доцент Пензенского государственного университета sts123@bk.ru 440026, Россия, г. Пенза, ул. Красная, д. 40 
- теории государства и права и политологии (заведующий кафедрой - доктор исторических наук, доктор юридических наук, профессор Алексей Юрьевич Саломатин);

- уголовного права (заведующий кафедрой доктор юридических наук, профессор Георгий Борисович Романовский);

- частного и публичного права (заведующий кафедрой - доктор юридических наук, профессор Глеб Владимирович Синцов);

- правоохранительной деятельности (заведующий кафедрой - кандидат юридических наук, доцент Николай Иванович Свечников). В 1998-2004 гг. деканом юридического факультета был кандидат исторических наук, доцент В. В. Еремин, в 2004-2006 гг. - доктор юридических наук, доктор исторических наук, профессор А. Ю. Саломатин.

В августе 2006 г. деканом юридического факультета стал Виталий Владимирович Гошуляк - доктор юридических наук и доктор исторических наук, профессор, действительный член Российской академии социальных наук, член экспертного совета Российского фонда фундаментальных исследований, член квалификационной коллегии судей Пензенской области. С этого момента стратегия развития юридического факультета кардинально изменилась. Были открыты специальности «Правоохранительная деятельность», магистратура, аспирантура. Налажены международные образовательные и научные контакты. За это время значительно увеличилось количество защит кандидатских и докторских диссертаций по юридическим наукам. Была поставлена задача - реализация идеи многоуровневой системы юридического образования в Университете: «среднее профессиональное образование - бакалавриат - магистратура - аспирантура - докторантура». В 2011 г. В. В. Гошуляку присвоено звание почетного работника высшего профессионального образования Российской Федерации.

В настоящее время на юридическом факультете обучается более 3500 студентов, аспирантов и магистров. В учебном процессе по направлению «Юриспруденция» и специальности «Правоохранительная деятельность» участвуют 8 докторов и 30 кандидатов юридических наук. По всем специальностям активно идет сотрудничество с практикующими юристами. Аудиторные занятия проводят сотрудники правоохранительных органов, федеральные судьи, судьи системы арбитражных судов, адвокаты. Тесные контакты налажены с правительством Пензенской области, Пензенским областным судом, Арбитражным судом Пензенской области, Нотариальной палатой Пензенской области, УФСИН по Пензенской области, Управлением по обеспечению деятельности мировых судей в Пензенской области, Законодательным собранием Пензенской области. Так, профессор Г.Б. Романовский является председателем комиссии по вопросам помилования при губернаторе Пензенской области; профессора Г.Б. Романовский и Г. В. Синцов - члены экзаменационной комиссии Пензенской области по приему квалификационного экзамена на должность судьи; профессор О. В. Романовская и доценты Н. И. Свечников, О. А. Рыжова, А. А. Шамшов, В. Н. Колемасов - члены квалификационной коллегии судей.

Факультет располагает значительной учебно-материальной базой, в составе которой лаборатория криминалистики, криминалистический полигон, класс огневой подготовки и специальной техники, класс оперативно-розыскной деятельности и тактико-специальной подготовки, тир, класс рукопашного боя.

На криминалистическом полигоне студенты осуществляют осмотр «места происшествия или преступления», отрабатывают тактику проведения следственных действий, а также осваивают правила оформления процессуальных документов. Класс огневой подготовки и специальной техники оснащен интерактивным лазерным тиром, позволяющим студентам приобретать знания по устройству оружия и навыки по его применению, а также знакомиться с современными техническими средствами, применяемыми правоохранительными органами для обеспечения общественной и государственной безопасности.

По окончании вуза большинство студентов переходят в сферу правоприменительной деятельности, поэтому на факультете сделан акцент на усиление практической составляющей учебного процесса. Для того чтобы учебный процесс в большей степени приблизить к правовому применению и реальной юридической жизни, кафедра правосудия оборудовала два учебных зала судебных заседаний, которые оснащены современной оргтехникой: компьютерами, мультимедийным оборудованием, телевизионными экранами, интерактивными досками, документокамерами; сформирован архив учебных судебных дел. 
Преподаватель при чтении лекции имеет возможность с помощью документокамеры вывести на телевизионный экран или настенную панель любой процессуальный документ, находящийся в судебном деле, и наглядно продемонстрировать его структуру и содержание. Студент на семинарских занятиях имеет возможность по материалам конкретного дела проследить особенности его расследования и судебного разбирательства, тактику производства того или иного следственного (судебного) действия, стадии правоприменительного процесса и т.д.

В целом кафедральный комплекс позволяет при проведении учебных занятий не только моделировать правовые казусы, но и брать их из нашей каждодневной юридической практики. А главное, здесь проводятся учебные следственные действия, судебные процессы, разрешаются юридические конфликты по существу, готовятся процессуальные документы и т.д.

Для углубления специализации бакалавров на факультете открыты магистратуры по программам: «Конституционное право; муниципальное право»; «Правовая политика в Российской Федерации и странах Евросоюза»; «Уголовное право»; «Гражданское право; предпринимательское право»; «Судебная, прокурорская, адвокатская защита».

С 2011 по 2015 г. открыты учебные лаборатории для магистров и аспирантов, которые оборудованы современными рабочими станциями.

В июне 2010 г. в состав юридического факультета вошел юридический колледж Университета. С этого времени юридический факультет стал готовить специалистов не только с высшим, но и со средним профессиональным образованием. Юридический колледж создан в 1999 году. За это время подготовлено более 300 специалистов со средним профессиональным образованием. С октября 2014 г. колледж преобразован в многопрофильный колледж. Накопленный за это время опыт учебной работы подтверждает жизнеспособность и актуальность идеи многоуровневого образования.

В декабре 2009 г. на базе юридического факультета был сформирован Центр бесплатной юридической помощи населению. Центр открывает свои двери с началом каждого учебного семестра. Активную поддержку в работе Центра оказывает Пензенское региональное отделение Ассоциации юристов России. Целями создания консультации являются оказание бесплатной юридической помощи малоимущим гражданам, повышение уровня подготовки студентов, расширение сотрудничества с местными судебными и иными правоохранительными органами, общественными организациями, развитие сотрудничества с центрами оказания правовой помощи населению других регионов России.

Приказом Минобрнауки России от 22 сентября 2015 г. на факультете открыт объединенный диссертационный совет по защите диссертаций на соискание ученой степени кандидата юридических наук, доктора юридических наук.

Большую роль в научной работе на факультете играют научно-образовательный центр (НОЦ) «Сравнительная правовая политика», созданный 30 марта 2010 г. в результате соглашения между Университетом и Саратовским филиалом Института государства и права РАН (руководитель - профессор А. Ю. Саломатин). НОЦ проводит исследования в области сравнительного правоведения и политологии, государственно-правовой глобалистики, изучает зарубежный опыт, опыт РФ и российских регионов в осуществлении правовой политики. Центром изданы учебно-методические комплексы и учебники в центральных издательствах «Норма», «Юридический центр-Пресс», «Юристъ», «Юрайт». Важным для НОЦ стал выпуск сборников статей и информационно-методических материалов «Сравнительное правоведение в российском высшем образовании», «Компаративистика-2010: сравнительное правоведение, сравнительное государствоведение, сравнительная политология», "Comparative legal policy: preliminary concepts» и др. НОЦ имеет партнерские связи с Украинской ассоциацией сравнительного правоведения; кафедрой теории права и сравнительного правоведения Национального исследовательского университета «Высшая школа экономики», кафедрой европейского права и сравнительного правоведения Саратовской государственной юридической академии. В 2013 г. руководитель НОЦ «Сравнительная правовая политика» А. Ю. Саломатин возглавил юридический журнал «Сравнительная правовая и политические исследования».

В 2014 г. создан Научно-исследовательский центр по проблемам современного федерализма. Центром подготовлены монографии и учебные пособия, выпущенные в издательствах Москвы и Пензы на русском и английском языках. 
С 2007 г. на юридический факультет был переведен юридический адрес Пензенской региональной общественной организации Союза юристов Пензенской области, объединяющей в своих рядах высококвалифицированных юристов по профессиональному признаку. Организация вступила в Ассоциацию юристов России в виде Пензенского регионального отделения Ассоциации юристов России. Это событие является значимым для юридического факультета, поскольку Ассоциация юристов России постоянно оказывает юридические услуги населению и занимается правовым просвещением.

Юридический факультет активно развивает международное сотрудничество. Многие преподаватели университета прошли зарубежные научные стажировки:

С. Т. Сулейманова (2003 г. - стажировка по гранту на юридическом факультете в университете г. Оттавы для составления спецкурса по основам уголовного права Канады);

А. В. Александрова (1999 г. - стажировка по вопросам городской социальной политики в отношении молодежи в Национальном институте молодежи и образования в г. Марлиле-Руа, Франция; 2001 г. - стажировка в Центре сравнительного трудового и социального права при Университете Бордо IV);

П. А. Гук (2011 г. - стажировка в США).

В 2014 г. Пензенский государственный университет и Университет г. Фленсбург (Германия) начали реализацию совместного образовательного и научного проекта по изучению юриспруденции и политических наук. Университеты заключили соглашение о совместной образовательной инициативе, в рамках которой магистранты Германии начали в дистанционном режиме изучать дисциплину «Сравнительная правовая политика». Завершением изучения стала международная конференция магистрантов во Фленсбурге (в конференции принимали участие магистранты, обучающиеся по программе «Правовая политика в РФ и странах Евросоюза», профессор А. Ю. Саломатин, доцент С. Т. Сулейманова).

Преподаватели факультета активно участвуют в международных конференциях по правовым проблемам, например в международных семинарах в Центре сравнительного трудового и социального права при Университете Бордо IV. В 2014 г. профессор А. Ю. Саломатин участвовал в работе XIX Конгресса по сравнительному праву в г. Вене (Австрия).
От преподавателей стараются не отставать и студенты. Они принимают активное участие во всероссийских и международных конкурсах, олимпиадах, конференциях и получают заслуженные награды.

Пензенским региональным отделением Ассоциации юристов России совместно с Пензенским государственным университетом с 15 сентября по 20 сентября 2010 г. в г. Одессе была проведена Первая Российская юридическая неделя на Украине.

Ученые из разных стран (Германии, Бельгии, США, Китая и др.) нередко становятся приглашенными профессорами юридического факультета. В октябре 2011 г. представители Американского союза юристов посетили Пензенский государственный университет. Действующие адвокаты чикагской фирмы Latham \& Watkins, преподаватели Майкл Фэрис и Маргарет Кирни выступили с докладами, пообщались со студентами юридического факультета. Преподаватели Иллинойского университета рассказали студентам о проблемах американского федерализма, правовой системы и о юридических прецедентах Верховного суда США.

В мае 2014 г. на факультете была проведена международная конференция на тему «Сравнительная правовая политика как важнейшее направление юридической науки», на которую прибыли ученые-юристы из Германии, Венгрии, КНР. Летом 2015 г. профессор А. Ю. Саломатин избран членом-корреспондентом Международной академии сравнительного права.

Преподаватели факультета неоднократно получали гранты на научные исследования в Российском фонде фундаментальных исследований, Российском гуманитарном научном фонде, от зарубежных фондов. Ежегодно преподаватели юридического факультета публикуют свыше 400 научных работ, из них более 100 в журналах, рекомендованных ВАК. Профессор Г. Б. Романовский является автором главы, посвященной праву на неприкосновенность частной жизни, в монографии, трижды изданной в России, переведенной на английский язык, изданной в США и разосланной в ведущие вузы мира.

Таким образом, юридический факультет является базовым и единственным профильным для Пензенской области в подготовке специалистов-юристов, который ставит перед собой задачу не только подготовки высококвалифицированных специалистов, но и участия в различных российских и международных научных проектах. 


\section{FACULTY OF LAW OF THE PENZA STATE UNIVERSITY}

FEOKTISTOV Aleksandr Vladimirovich - Ph.D., Associate Dean of the Law Faculty for Social and Educational Work at the Penza State University ufdec@pnzgu.ru

440026, Russia, Penza, ul. Krasnaya, d. 40.

SULEYMANOVA Svetlana Timurovna - Ph.D. in Social Sciences, Ph.D. in Law, Associate Professor at the Penza State University sts_123@bk.ru

440026, Russia, Penza, ul. Krasnaya, d. 40.

Review. This article describes the process of formation of the Faculty of Law of the Penza State University. Despite the fact that the Faculty is relatively young, it has accumulated a lot of experience in teaching, scientific research, international cooperation, participation in different projects. On the basis of the Faculty of Law the Center providing free legal aid to the population was formed. An important role in scientific work of the Faculty is played by the Scientific and Educational Center "Comparative Legal Policy" and the Research Center "The Challenges of Modern Federalism". The Faculty is actively developing international cooperation. Many University professors have undergone scientific internships in foreign universities; have repeatedly received grants for scientific research from the Russian Fund of Fundamental Research, Russian Humanitarian Scientific Fund, and foreign funds. Scholars from different countries (Germany, Belgium, the United States, China, etc.) are often invited as visiting professors of the Faculty of Law.

Keywords: Penza University, history of the Faculty, educational activities, scientific research, international cooperation, legal assistance, research, departments. 